\title{
Simulation of a Plant for the Production of Polyethylene
}

\author{
Emiowele Preye, Jackson G. Akpa, Patience Ikenyiri \\ Department of Chemical/Petrochemical Engineering, Rivers State University, Nkpolu-Oroworukwu, Port Harcourt, \\ Nigeria \\ Email: P.emiowele@yahoo.coms
}

How to cite this paper: Preye, E., Akpa, J.G. and Ikenyiri, P. (2020) Simulation of a Plant for the Production of Polyethylene. Advances in Chemical Engineering and Science, 10, 408-422.

https://doi.org/10.4236/aces.2020.104026

Received: August 7, 2020

Accepted: October 27, 2020

Published: October 30, 2020

Copyright $\odot 2020$ by author(s) and Scientific Research Publishing Inc. This work is licensed under the Creative Commons Attribution International License (CC BY 4.0).

http://creativecommons.org/licenses/by/4.0/

\begin{abstract}
The simulation of a 270 KTA capacity polyethylene plant was performed using Aspen Hysys version 8.8. A Hysys model of the polyethylene was developed using the polyethylene plant layout of Indorama Eleme Petrochemical Company. A material and energy balance for the various components of the plant was performed manually and with Hysys for comparison. The design of the various components of the Hysys model was performed. The polyethylene reactor was simulated to study the effect of process functional parameters such as reactor dimensions, temperature and pressure. The effect of reactor size and number on polyethylene output was studied by simulating the plant with five continuous stirred tank reactors (CSTRs) in series and a single reactor. The results of the material and energy balance of the various components of the plant were performed manually and with Hysys which showed a maximum deviation of $0.8 \%$. The design results of the sizing parameters for the Multiple and single CSTRs were compared in terms of Volume, Diameter, Height, Spacetime, Space Velocity, and Volumetric flowrate respectively. At $90 \%$ Conversion, the multiple CSTRs gave $600 \mathrm{dm}^{3}, 0.7668 \mathrm{~m}, 1.198 \mathrm{~m}, 0.052$ $\mathrm{hr}, 195.83 \mathrm{hr}^{-1}$, and $117.5 \mathrm{~m}^{3} / \mathrm{h}$ for the above listed parameters, while the single CSTR gave $6000 \mathrm{dm}^{3}, 1.721 \mathrm{~m}, 2.581 \mathrm{~m}, 0.056 \mathrm{hr}, 17.867 \mathrm{hr}^{-1}$ and 107.2 $\mathrm{m}^{3} / \mathrm{h}$ for the same conversion. The sizing results for each of the five compressors were also compared in terms of the following parameters: Adiabatic Head, Polytropic Head, Adiabatic fluid Head, polytropic Fluid Head, Adiabatic Efficiency, power consumed, polytropic head factor, polytropic exponent and isentropic exponent. The effect of reactor size and number showed that At $90 \%$ conversion the multiple CSTRS in series gave a lower volume than the single CSTR for the same conversion, and more Economical than the single CSTR for the same conversion.
\end{abstract}

\section{Keywords}

Simulation, Compressor, Conversion, Hysys, CSTR 


\section{Introduction}

Olefins manufacturing is the third largest petrochemical industry after others like ammonia manufacturing and petroleum refining. Polyethylene has been extensively applied in industries chemicals and other related products are been manufactured all round the world [1].

Polyethylene is used as starting material for the production products such as: cosmetics, plastics, solvents etc. having a high market demand with production rate of 150,000,000 tons/year and this production rate has been predicted to rise by 3.5 percent in the next five years [2]. A large amount of polyethylene is used for producing plastics which contains polymer chains of ethylene units in its numerous chain lengths. [3] researched on non-catalytic pyrolysis of ethane to ethylene in the presence of $\mathrm{CO}_{2}$ with or without limited $\mathrm{CO}_{2}$. Both presence and absence of limited $\mathrm{CO}_{2}$ in the pyrolysis of ethane to ethylene at process conditions of $750^{\circ} \mathrm{C}-900^{\circ} \mathrm{C}$, space velocities of $1500-9000$ per hour and $\mathrm{CO}_{2} / \mathrm{C}_{2} \mathrm{H}_{6}$ and $\mathrm{O}_{2} / \mathrm{C}_{2} \mathrm{H}_{6}$ nude ratios ( $0-2.0$ and $0-3.0$ respectively), and ethane conversion increases [4]. The activation of ethane in the presence of $\mathrm{C}_{2}$ increases the formation of ethylene but not oxidation of ethane.

[5] researched on Ethylene production plant design 700 metric tons per day of ethylene production plant was carried using $140,010 \mathrm{lb} / \mathrm{hr}$ of $10 \%$ butane which was fed with $100 \%$ of $8174 \mathrm{lb} / \mathrm{hr}$ ethane recycled from the furnace reactor. Other products obtained were propylene, gasoline and high-pressure steam products are subsequently sold [6]. The expectation of the ethylene plant is to profit 160 million over a 10 yrs operation period and a returned investment of $16 \%$. The plant was expected to $8400 \mathrm{hrs}$ a year of 0.96 operating factors. The capital investment of the plant was $\$ 28,000,000$ and $\$ 16,000,000$ per year of auxiliary equipment and gave an annual operating cost of $\$ 20,500$ per yr.

[7] worked on simulation and analysis of ethane cracking process. Coiled tubular reactors were used for the processing and cracking of light hydrocarbons (Ethane, propane, $\mathrm{n}$-butane and their mixtures) at high temperatures and short residence times to obtained ethylene as the main product. The simulation of the industrial reactor unit with ethane as a feedstock for the molecular reaction scheme of 8 components and five (5) reactions was done. The predicted models result using plant data were compared with the industrial data and gave small derivations interns of pressure and temperature but negligible deviation with concentration. Also, the profile of temperatures and concentration for both models results and industrial results agrees.

[8] Ethylene is of great importance to the petrochemical industry where varieties of products such as bottles, housewares, antifreeze, food containers, pipes, carpets, toys, film, etc., the various chemicals produced from ethylene as raw material include: vinyl acetate, ethylene oxide, ethyl benzene, polyethylene, ethylene dichloride etc.

[9] Polyvinyl chloride which is a byproduct of polyethylene accounts for about $70 \%$ usage in construction materials, pipe fittings, windows etc. and about 30\% 
is used in making cable wires, coating surfaces and plastic manufacture.

[10] worked on how ethylene can be obtained from natural gas through the method of oxidative coupling of methane and cold energy of LNG. Liquefied Natural Gas was used as feedstock for the oxidative coupling of methane and thereafter through cryogenic distillation process, ethylene was obtained, it was discovered that production cost of ethylene greatly depends on the market price of LNG and NG which was shown through the difference in price of LNG/NG as well as other co-products affects the cost of production of ethylene.

Worldwide production rate of Polyethylene is known to be about 85 metric ton/year due to its high demand and usage [11]. Figure 1 shows the process flow diagram for the production of polyethylene, it consists of three reactors namely: polymerization reactor operating at 6.5 bar and $50.7^{\circ} \mathrm{C}$, loop reactor operating at 6.5 bar $70.9^{\circ} \mathrm{C}$ and finally gas phase reactor operating at 6.5 bar and $70.9^{\circ} \mathrm{C}$.

The purpose of this research is to design and simulate a process plant for the production of polyethylene using Aspen Hsys Veesion 8.8 software.

\section{Materials and Methods}

\subsection{Materials}

The Materials used in this work are Data from Indorama Eleme Petrochemicals Limited which includes:

1) Detailed process flow diagram.

2) Inlet feed operating conditions.

3) Comprehensive feed compositions.

4) Utilities.

5) Aspen Hysys Version 8.8 software.

6) Laptop.

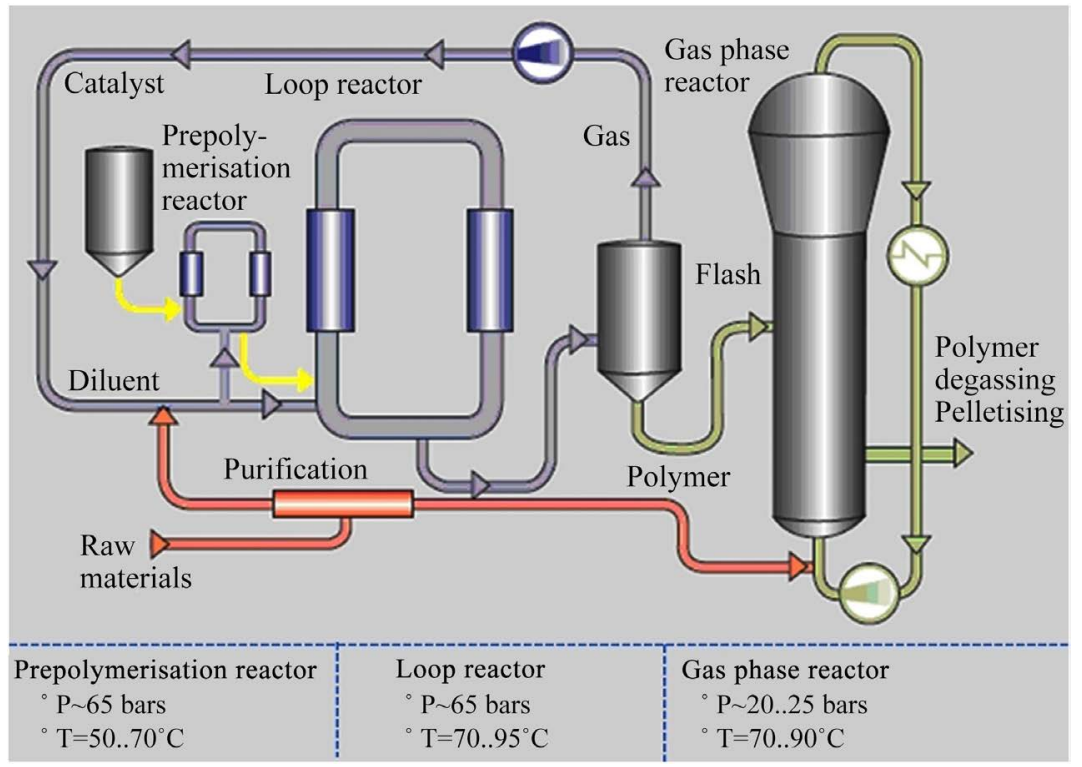

Figure 1. PFD of polyethylene plant production. 
7) Chemical Engineering related Handbooks etc.

\subsection{Methods}

The methods used to accomplish this research are outlined as follows:

1) Perform material and energy balance on each equipment unit using the principles of conservation of mass and energy.

2) Build the Hysys process model of the plant.

3) Carry out sensitivity analysis.

1) The material balance equation for each equipment unit can be written as follows:

(Rate of accumulation of component $i$ wihtin the reactor)

$=($ Rate of input of component $\mathrm{i})-($ Rate of output of component $\mathrm{i})$

$+($ Rate of Generation of component i)

$-($ Rate of Consumption of component i)

The energy balance equation for each eqipment unit can be written as follows:

(Rate of accumulation of energy $)=($ Rate of inflow of energy $)$

$-($ Rate of outflow of total energy $)+($ Rate of energy supplied by heat $)$

2) Hysys model

This involves building of the plant model into hysys for both the single and multiple reactor cases as shown in Figure 2 and Figure 3 respectively.

\section{Results and Discussion}

\subsection{Material Balance Result}

The material balance results are presented in Tables 1-6 for all the various streams and units.

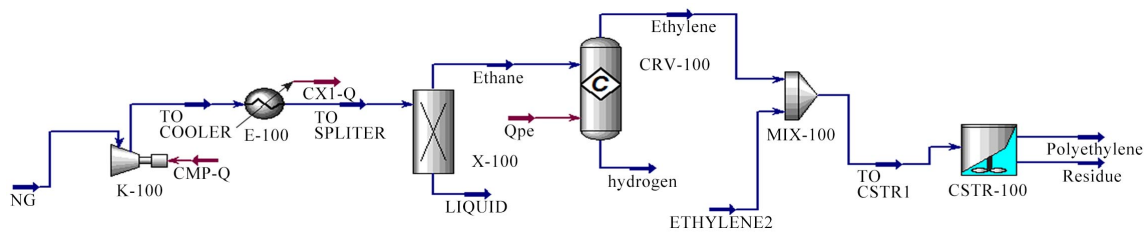

Figure 2. Hysys model for single CSTR for polyethylene plant.

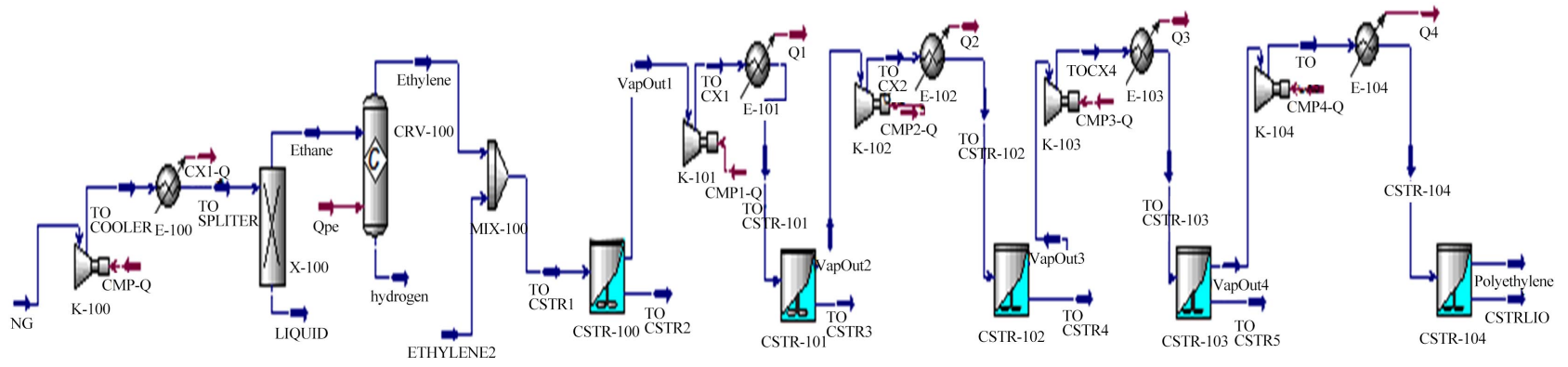

Figure 3. Hysys model for multiple CSTRs for polyethylene plant. 
Table 1. Comparison of material balance results of hysys simulation with manual calculation for compression unit.

\begin{tabular}{cccc}
\hline Stream & Manual Calculation & Hysys Simulation & \% Deviation \\
\hline NG & & & \\
Mass flow $(\mathrm{kg} / \mathrm{h})$ & $1.852 \mathrm{E} 6$ & $1.848 \mathrm{E} 6$ & 0.2 \\
MolarFlow $(\mathrm{kgmole} / \mathrm{hr})$ & $1.029 \mathrm{E} 5$ & $1.026 \mathrm{E} 5$ & 0.3 \\
To Cooler & & & \\
Mass flow $(\mathrm{kg} / \mathrm{h})$ & $1.852 \mathrm{E} 6$ & $1.848 \mathrm{E} 6$ & 0.2 \\
MolarFlow $(\mathrm{kgmole} / \mathrm{hr})$ & $1.029 \mathrm{E} 5$ & $1.026 \mathrm{E} 5$ & 0.3 \\
\hline
\end{tabular}

Table 2. Comparison of material balance results of hysys simulation with manual calculation for cooling unit.

\begin{tabular}{cccc}
\hline Stream & Manual Calculation & Hysys Simulation & \% Deviation \\
\hline To Cooler & & & \\
Mass flow $(\mathrm{kg} / \mathrm{h})$ & $1.852 \mathrm{E} 6$ & $1.848 \mathrm{E} 6$ & 0.2 \\
MolarFlow $(\mathrm{kgmole} / \mathrm{hr})$ & $1.029 \mathrm{E} 5$ & $1.026 \mathrm{E} 5$ & 0.3 \\
To Splitter & & & \\
Mass flow $(\mathrm{kg} / \mathrm{h})$ & $1.852 \mathrm{E} 6$ & $1.848 \mathrm{E} 6$ & 0.2 \\
MolarFlow $(\mathrm{kgmole} / \mathrm{hr})$ & $1.029 \mathrm{E} 5$ & $1.026 \mathrm{E} 5$ & 0.3 \\
\hline
\end{tabular}

Table 3. Comparison of material balance results of hysys simulation with manual calculation for splitting unit.

\begin{tabular}{cccc}
\hline Stream & Manual Calculation & Hysys Simulation & \% Deviation \\
\hline To Splitter & & & \\
Mass flow $(\mathrm{kg} / \mathrm{h})$ & $1.852 \mathrm{E} 6$ & $1.848 \mathrm{E} 6$ & 0.2 \\
Molar flow $(\mathrm{kgmole} / \mathrm{hr})$ & $1.029 \mathrm{E} 5$ & $1.026 \mathrm{E} 5$ & 0.3 \\
Ethane & & & 0.5 \\
Mass flow $(\mathrm{kg} / \mathrm{h})$ & $3.516 \mathrm{E} 4$ & $3.514 \mathrm{E} 4$ & 0.3 \\
Molar flow $(\mathrm{kgmole} / \mathrm{hr})$ & 1169 & 1172 & \\
Liquid & & & 0.3 \\
Mass flow $(\mathrm{kg} / \mathrm{h})$ & $1.817 \mathrm{E} 6$ & $1.812 \mathrm{E} 6$ & 0.2 \\
Molar flow $(\mathrm{kgmole} / \mathrm{hr})$ & $1.017 \mathrm{E} 5$ & $1.015 \mathrm{E} 5$ & \\
\hline
\end{tabular}

Table 4. Comparison of material balance results of hysys simulation with manual calculation for conversion reactor unit.

\begin{tabular}{cccc}
\hline Stream & Manual Calculation & Hysys Simulation & \% Deviation \\
\hline Ethane & & & \\
Mass flow $(\mathrm{kg} / \mathrm{h})$ & $3.516 \mathrm{E} 4$ & $3.514 \mathrm{E} 4$ & 0.5 \\
Molar flow $(\mathrm{kgmole} / \mathrm{hr})$ & 1169 & 1172 & 0.3 \\
Ethylene & & & \\
Mass flow $(\mathrm{kg} / \mathrm{h})$ & $3.516 \mathrm{E} 4$ & $3.512 \mathrm{E} 4$ & 0.1 \\
Molar flow $(\mathrm{kgmole} / \mathrm{hr})$ & 1637 & 1632 & 0.3 \\
\hline
\end{tabular}


Table 5. Comparison of material balance results of hysys simulation with manual calculation for mixing unit.

\begin{tabular}{cccc}
\hline Stream & Manual Calculation & Hysys Simulation & \% Deviation \\
\hline Ethylene & & & \\
Mass flow $(\mathrm{kg} / \mathrm{h})$ & $3.516 \mathrm{E} 4$ & $3.512 \mathrm{E} 4$ & 0.1 \\
Molar flow (kgmole/hr) & 1637 & 1632 & 0.3 \\
Ethylene 2 & & & 0.1 \\
Mass flow (kg/h) & 56.95 & 56.89 & 0.8 \\
Molar flow (kgmole/hr) & 2.651 & 2.631 & \\
To CSTR1 & & & 0.1 \\
Mass flow (kg/h) & $3.522 \mathrm{E} 4$ & $3.518 \mathrm{E} 4$ & 0.6 \\
Molar flow (kgmole/hr) & 1640 & 1650 & \\
\hline
\end{tabular}

Table 6. Comparison of material balance results of hysys simulation with manual calculation for CSTR unit.

\begin{tabular}{cccc}
\hline Stream & Manual Calculation & Hysys Simulation & \% Deviation \\
\hline To CSTR1 & & & \\
Mass flow $(\mathrm{kg} / \mathrm{h})$ & $3.522 \mathrm{E} 4$ & $3.518 \mathrm{E} 4$ & 0.1 \\
Molar flow (kgmole/hr) & 1640 & 1650 & 0.6 \\
Polyethylene & & & 0.1 \\
Mass flow (kg/h) & $3.522 \mathrm{E} 4$ & $3.518 \mathrm{E} 4$ & 0.6 \\
Molar flow (kgmole/hr) & 1640 & 1650 & \\
\hline
\end{tabular}

\subsection{Energy Balance Result}

The energy balance results are presented in Tables 7-12 for all the various streams and units.

Table 7. Comparison of energy balance results of hysys simulation with manual calculation for compression unit.

\begin{tabular}{cccc}
\hline Stream & Manual Calculation & Hysys Simulation & \% Deviation \\
\hline NG & 30 & 30 & 0.2 \\
Temperature $\left({ }^{\circ} \mathrm{C}\right)$ & 101.3 & 101.3 & 0.3 \\
Pressure $(\mathrm{KPa})$ & $-8.564 \mathrm{E} 9$ & $-8.567 \mathrm{E} 9$ & 0.2 \\
Heat flow $(\mathrm{KJ} / \mathrm{Hr})$ & & & 0.2 \\
To Cooler & 92.15 & 92.15 & 0.0 \\
Temperature $\left({ }^{\circ} \mathrm{C}\right)$ & 200 & 200 & 0.3 \\
Pressure $(\mathrm{KPa})$ & $-8.3 .12 \mathrm{E} 9$ & $-8.315 \mathrm{E} 9$ & \\
Heat flow $(\mathrm{KJ} / \mathrm{Hr})$ & &
\end{tabular}


Table 8. Comparison of material balance results of hysys simulation with manual calculation for cooling unit.

\begin{tabular}{cccc}
\hline Stream & Manual Calculation & Hysys Simulation & \% Deviation \\
\hline To Cooler & & & \\
Temperature $\left({ }^{\circ} \mathrm{C}\right)$ & 92.15 & 92.15 & 0.0 \\
Pressure $(\mathrm{KPa})$ & 200 & 200 & 0.0 \\
Heat flow $(\mathrm{KJ} / \mathrm{Hr})$ & $-8.312 \mathrm{E} 9$ & $-8.315 \mathrm{E} 9$ & 0.3 \\
To Splitter & & & \\
Temperature $\left({ }^{\circ} \mathrm{C}\right)$ & 45 & 45 & 0.2 \\
Pressure $(\mathrm{KPa})$ & 200 & 200 & 0.0 \\
Heat flow $(\mathrm{KJ} / \mathrm{Hr})$ & $-8.512 \mathrm{E} 9$ & $-8.510 \mathrm{E} 9$ & 0.3 \\
\hline
\end{tabular}

Table 9. Comparison of energy balance results of hysys simulation with manual calculation for splitting unit.

\begin{tabular}{cccc}
\hline Stream & Manual Calculation & Hysys Simulation & \% Deviation \\
\hline To Splitter & & & \\
Temperature $\left({ }^{\circ} \mathrm{C}\right)$ & 45 & 45 & 0.0 \\
Pressure $(\mathrm{KPa})$ & 200 & $-8.510 \mathrm{E} 9$ & 0.0 \\
Heat flow $(\mathrm{KJ} / \mathrm{Hr})$ & $-8.513 \mathrm{E} 9$ & & 0.3 \\
Ethane & & 56 & 0.0 \\
Temperature $\left({ }^{\circ} \mathrm{C}\right)$ & $3.516 \mathrm{E} 4$ & 100 & 0.0 \\
Pressure $(\mathrm{KPa})$ & 100 & $-9.716 \mathrm{E} 7$ & 0.3 \\
Heat flow $(\mathrm{KJ} / \mathrm{Hr})$ & $-9.712 \mathrm{E} 7$ & & 0.0 \\
Liquid & & 44.31 & 0.0 \\
Temperature $\left({ }^{\circ} \mathrm{C}\right)$ & 44.31 & 100 & 0.1 \\
Pressure $(\mathrm{KPa})$ & 100 & $-8.413 \mathrm{E} 9$ & \\
Heat flow $(\mathrm{KJ} / \mathrm{Hr})$ & $-8.415 \mathrm{E} 9$ & & \\
\hline
\end{tabular}

Table 10. Comparison of energy balance results of hysys simulation with manual calculation for conversion reactor unit.

\begin{tabular}{cccc}
\hline Stream & Manual Calculation & Hysys Simulation & \% Deviation \\
\hline Ethane & & & \\
Temperature $\left({ }^{\circ} \mathrm{C}\right)$ & 56 & 56 & 0.0 \\
Pressure $(\mathrm{KPa})$ & 100 & $-9.716 \mathrm{E} 7$ & 0.0 \\
Heat flow $(\mathrm{KJ} / \mathrm{Hr})$ & $-9.714 \mathrm{E} 7$ & & 0.3 \\
Ethylene & & 60 & 0.0 \\
Temperature $\left({ }^{\circ} \mathrm{C}\right)$ & 60 & 100 & 0.0 \\
Pressure $(\mathrm{KPa})$ & 100 & $4.807 \mathrm{E} 7$ & 0.3 \\
Heat flow $(\mathrm{KJ} / \mathrm{Hr})$ & 1637 & & \\
\hline
\end{tabular}


Table 11. Comparison of energy balance results of hysys simulation with manual calculation for mixing unit.

\begin{tabular}{cccc}
\hline Stream & Manual Calculation & Hysys Simulation & \% Deviation \\
\hline Ethylene & & & \\
Temperature $\left({ }^{\circ} \mathrm{C}\right)$ & 60 & 100 & 0.0 \\
Pressure $(\mathrm{KPa})$ & 100 & $4.807 \mathrm{E} 7$ & 0.0 \\
Heat flow $(\mathrm{KJ} / \mathrm{Hr})$ & $4.807 \mathrm{E} 7$ & & 0.0 \\
Ethylene 2 & & 56 & 0.0 \\
Temperature $\left({ }^{\circ} \mathrm{C}\right)$ & 56 & 100 & 0.0 \\
Pressure $(\mathrm{KPa})$ & 100 & $-5.306 \mathrm{E} 4$ & 0.8 \\
Heat flow $(\mathrm{KJ} / \mathrm{Hr})$ & $-5.306 \mathrm{E} 4$ & & 0.0 \\
To CSTR1 & & 59.99 & 0.00 \\
Temperature $\left({ }^{\circ} \mathrm{C}\right)$ & 59.99 & 100 & 0.3 \\
Pressure $(\mathrm{KPa})$ & 100 & $4.807 \mathrm{E} 7$ & \\
Heat flow $(\mathrm{KJ} / \mathrm{Hr})$ & $4.802 \mathrm{E} 7$ & & \\
\hline
\end{tabular}

Table 12. Comparison of energy balance results of hysys simulation with manual calculation for cstr unit.

\begin{tabular}{cccc}
\hline Stream & Manual Calculation & Hysys Simulation & \% Deviation \\
\hline To CSTR1 & 59.99 & 59.99 & 0.0 \\
Temperature $\left({ }^{\circ} \mathrm{C}\right)$ & 100 & 100 & 0.0 \\
Pressure $(\mathrm{KPa})$ & $4.805 \mathrm{E} 7$ & $4.807 \mathrm{E} 7$ & 0.3 \\
Heat flow $(\mathrm{KJ} / \mathrm{Hr})$ & & & \\
Polyethylene & 68 & 68 & 0.0 \\
Temperature $\left({ }^{\circ} \mathrm{C}\right)$ & 150 & 150 & 0.0 \\
Pressure $(\mathrm{KPa})$ & $4.876 \mathrm{E}$ & $4.870 \mathrm{E} 7$ & 0.2 \\
Heat flow $(\mathrm{KJ} / \mathrm{Hr})$ & & & \\
\hline
\end{tabular}

\subsection{Conversion Results}

The Conversion results of the reactor conditions for both the multiple CSTRs and Single CSTR is presented below.

\subsubsection{Multiple CSTR Results}

Table 13. CSTR 1 conditions at $40 \%$ conversion.

\begin{tabular}{ccc}
\hline $\mathrm{S} / \mathrm{N}$ & Parameter & Value \\
\hline 1 & Vapour Fraction & 1 \\
2 & Temperature $\left({ }^{\circ} \mathrm{C}\right)$ & 59.99 \\
3 & Pressure $(\mathrm{Kpa})$ & 100 \\
4 & Molar Flow $(\mathrm{kgmole} / \mathrm{h})$ & 1256 \\
5 & Mass Flow $(\mathrm{kg} / \mathrm{h})$ & 19380 \\
6 & Heat Flow $(\mathrm{Kj} / \mathrm{h})$ & $5.607 \mathrm{e}$ \\
\hline
\end{tabular}


Table 14. CSTR 2 conditions at 50\% conversion.

\begin{tabular}{ccc}
\hline $\mathrm{S} / \mathrm{N}$ & Parameter & Value \\
\hline 1 & Vapour Fraction & 1 \\
2 & Temperature $\left({ }^{\circ} \mathrm{C}\right)$ & 58 \\
3 & Pressure $(\mathrm{Kpa})$ & 120 \\
4 & Molar Flow $(\mathrm{kgmole} / \mathrm{h})$ & 1142 \\
5 & Mass Flow $(\mathrm{kg} / \mathrm{h})$ & 17613 \\
6 & Heat Flow $(\mathrm{Kj} / \mathrm{h})$ & $4.784 \mathrm{e} 7$ \\
\hline
\end{tabular}

Table 15 . CSTR 3 conditions at $60 \%$ conversion.

\begin{tabular}{ccc}
\hline S/N & Parameter & Value \\
\hline 1 & Vapour Fraction & 1 \\
2 & Temperature $\left({ }^{\circ} \mathrm{C}\right)$ & 58 \\
3 & Pressure $(\mathrm{Kpa})$ & 130 \\
4 & Molar Flow $(\mathrm{kgmole} / \mathrm{h})$ & 913 \\
5 & Mass Flow $(\mathrm{kg} / \mathrm{h})$ & 14091 \\
6 & Heat Flow $(\mathrm{Kj} / \mathrm{h})$ & $4.784 \mathrm{e} 7$ \\
\hline
\end{tabular}

Table 16. CSTR 4 conditions at $80 \%$ conversion.

\begin{tabular}{ccc}
\hline $\mathrm{S} / \mathrm{N}$ & Parameter & Value \\
\hline 1 & Vapour Fraction & 1 \\
2 & Temperature $\left({ }^{\circ} \mathrm{C}\right)$ & 69 \\
3 & Pressure $(\mathrm{Kpa})$ & 130 \\
4 & Molar Flow $(\mathrm{kgmole} / \mathrm{h})$ & 456 \\
5 & Mass Flow $(\mathrm{kg} / \mathrm{h})$ & 7045 \\
6 & Heat Flow $(\mathrm{Kj} / \mathrm{h})$ & $4.87 \mathrm{e} 7$ \\
\hline
\end{tabular}

Table 17. CSTR 5 conditions at $90 \%$ conversion.

\begin{tabular}{ccc}
\hline $\mathrm{S} / \mathrm{N}$ & Parameter & Value \\
\hline 1 & Vapour Fraction & 1 \\
2 & Temperature $\left({ }^{\circ} \mathrm{C}\right)$ & 68 \\
3 & Pressure $(\mathrm{Kpa})$ & 150 \\
4 & Molar Flow $(\mathrm{kgmole} / \mathrm{h})$ & 228 \\
5 & Mass Flow $(\mathrm{kg} / \mathrm{h})$ & 3523 \\
6 & Heat Flow $(\mathrm{Kj} / \mathrm{h})$ & $4.87 \mathrm{e} 7$ \\
\hline
\end{tabular}




\subsubsection{Sizing Results}

\section{1) Single CSTR Result}

Table 18. Single CSTR conditions at $90 \%$ conversion.

\begin{tabular}{ccc}
\hline $\mathrm{S} / \mathrm{N}$ & Parameter & Value \\
\hline 1 & Vapour Fraction & 1 \\
2 & Temperature $\left({ }^{\circ} \mathrm{C}\right)$ & 59.99 \\
3 & Pressure $(\mathrm{Kpa})$ & 100 \\
4 & Molar Flow $(\mathrm{kgmole} / \mathrm{h})$ & 164 \\
5 & Mass Flow $(\mathrm{kg} / \mathrm{h})$ & 3523 \\
6 & Heat Flow $(\mathrm{Kj} / \mathrm{h})$ & $-3.251 \mathrm{e} 7$ \\
\hline
\end{tabular}

\section{2) Multiple Reactor Sizing}

The size of the multiple CSTRs are fixed and hence the size is the same throughout

Table 19. Sizing for multiple CSTR.

\begin{tabular}{ccc}
\hline $\mathrm{S} / \mathrm{N}$ & Parameter & Value \\
\hline 1 & Volume $\left(\mathrm{dm}^{3}\right)$ & 600 \\
2 & Diameter $(\mathrm{m})$ & 0.7968 \\
3 & Height $(\mathrm{m})$ & 1.198 \\
4 & Space Time $(\mathrm{hr})$ & 0.0052 \\
5 & Space Velocty $(1 / \mathrm{hr})$ & 195.83 \\
6 & Volume flowrate $\left(\mathrm{m}^{3} / \mathrm{hr}\right)$ & 117.5 \\
\hline
\end{tabular}

Table 20. Sizing for single CSTR.

\begin{tabular}{ccc}
\hline $\mathrm{S} / \mathrm{N}$ & Parameter & Value \\
\hline 1 & Volume $\left(\mathrm{dm}^{3}\right)$ & 6000 \\
2 & Diameter $(\mathrm{m})$ & 1.721 \\
3 & Height $(\mathrm{m})$ & 2.581 \\
4 & Space Time $(\mathrm{hr})$ & 0.056 \\
5 & Space Velocty $(1 / \mathrm{hr})$ & 17.867 \\
6 & Volume flowrate $\left(\mathrm{m}^{3} / \mathrm{hr}\right)$ & 107.2 \\
\hline
\end{tabular}

From Tables 13-20 above, we observed that using multiple CSTRs in series at different conversions almost equals using a single CSTR at the same final conversion except that it leads to a non-isothermal behavior as temperature is not controlled as in the case of using multiple CSTRs in series. 


\subsection{Parameters for Compressor Sizing at $90 \%$ Conversion}

The sizing of the four compressors at $90 \%$ conversion is given in Tables $21-24$ below.

Table 21. Sizing Compressor 1.

\begin{tabular}{ccc}
\hline S/N & Parameter & Value \\
\hline 1 & Adiabatic Head $(\mathrm{m})$ & 3313 \\
2 & Polytropic Head $(\mathrm{m})$ & 3334 \\
3 & Adiabatic Fluid Head $(\mathrm{KJ} / \mathrm{Kg})$ & 32.49 \\
4 & Polytropic Fluid Head $(\mathrm{KJ} / \mathrm{Kg})$ & 32.69 \\
5 & Adiabatic Efficiency & 75.000 \\
6 & Polytropic Efficiency & 75.475 \\
7 & Power Consumed (KW) & 423.7 \\
8 & Polytropic Head Factor & 1.000 \\
9 & Polytropic Exponent & 1.3738 \\
10 & Isentropic Exponent & 1.2718 \\
\hline
\end{tabular}

Table 22. Sizing Compressor 2.

\begin{tabular}{ccc}
\hline S/N & Parameter & Value \\
\hline 1 & Adiabatic Head (m) & 1429 \\
2 & Polytropic Head (m) & 1433 \\
3 & Adiabatic Fluid Head (KJ/Kg) & 14.02 \\
4 & Polytropic Fluid Head (KJ/Kg) & 14.06 \\
5 & Adiabatic Efficiency & 75.000 \\
6 & Polytropic Efficiency & 75.213 \\
7 & Power Consumed (KW) & 1828 \\
8 & Polytropic Head Factor & 1.000 \\
9 & Polytropic Exponent & 1.4004 \\
10 & Isentropic Exponent & 1.2742 \\
\hline
\end{tabular}

Table 23. Sizing Compressor 3.

\begin{tabular}{ccc}
\hline S/N & Parameter & Value \\
\hline 1 & Adiabatic Head $(\mathrm{m})$ & 1322 \\
2 & Polytropic Head $(\mathrm{m})$ & 1326 \\
3 & Adiabatic Fluid Head (KJ/Kg) & 12.49 \\
4 & Polytropic Fluid Head (KJ/Kg) & 13.00 \\
5 & Adiabatic Efficiency & 75.000 \\
6 & Polytropic Efficiency & 75.198 \\
7 & Power Consumed (KW) & 169.1 \\
8 & Polytropic Head Factor & 1.000 \\
9 & Polytropic Exponent & 1.4007 \\
10 & Isentropic Exponent & 1.2743 \\
\hline
\end{tabular}


Table 24. Sizing Compressor 4.

\begin{tabular}{ccc}
\hline $\mathrm{S} / \mathrm{N}$ & Parameter & Value \\
\hline 1 & Adiabatic Head $(\mathrm{m})$ & 1366 \\
2 & Polytropic Head $(\mathrm{m})$ & 1370 \\
3 & Adiabatic Fluid Head (KJ/Kg) & 13.40 \\
4 & Polytropic Fluid Head (KJ/Kg) & 13.44 \\
5 & Adiabatic Efficiency & 75.000 \\
6 & Polytropic Efficiency & 75.195 \\
7 & Power Consumed (KW) & 174.8 \\
8 & Polytropic Head Factor & 1.000 \\
9 & Polytropic Exponent & 1.3935 \\
10 & Isentropic Exponent & 1.2698 \\
\hline
\end{tabular}

From Tables 21-24, we observe that a single CSTR requires a large volume at the same conversion with a multiple CSTRs in Series. The space time of the single CSTR is higher than that of the Multiple CSTR in since it just a single reactor so more time is spent to process a given volume of feed.

\subsection{Sensitivity Analysis}

A sensitivity analysis was performed to determine the effect of the following functional parameters given below.

\subsubsection{Variation of Fractional Conversion with Height of Reactor}

Figure 4 shows that the height of reactor increases with an increase in Fractional conversion. The increment is as a result of the formation of products along the height of the rector.

\subsubsection{Variation of Fractional Conversion with Volume of Reactor}

Figure 5 shows how Fractional Conversion is Changing with the Volume of the Reactor, as the volume of the Reactor increases so does the Fractional conversion until it reaches its maximum value of 0.9 .

\subsubsection{Temperature and Pressure Progression}

Figure 6 shows the behavior of Temperature with Fractional conversion, As the Temperature of the Reactor increases so does the fractional conversion as a result of the Heat of reaction released to form products which can either be exothermic or endothermic. When it is endothermic heat is absorbed from the environment but when it is exothermic heat is released to the environment.

\subsubsection{Pressure Variation with Fractional Conversion}

This is also seen to behaving like the Temperature graph where an increase in the pressure of the reactor also brings about increase in Fractional conversion as shown in Figure 7. 


\subsubsection{Variation of Space Time with Fractional Conversion}

Space time is also an important functional parameter in the design of continuous reactors. The space time gives the information of the amount of time required to process a given volume of feed at inlet conditions.

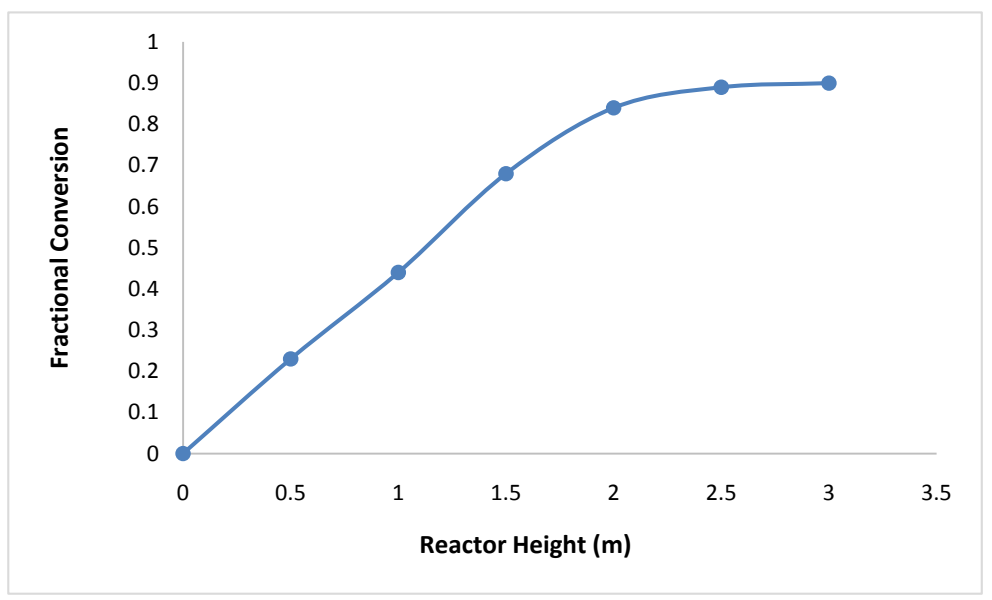

Figure 4. Variation of fractional conversion with reactor height.

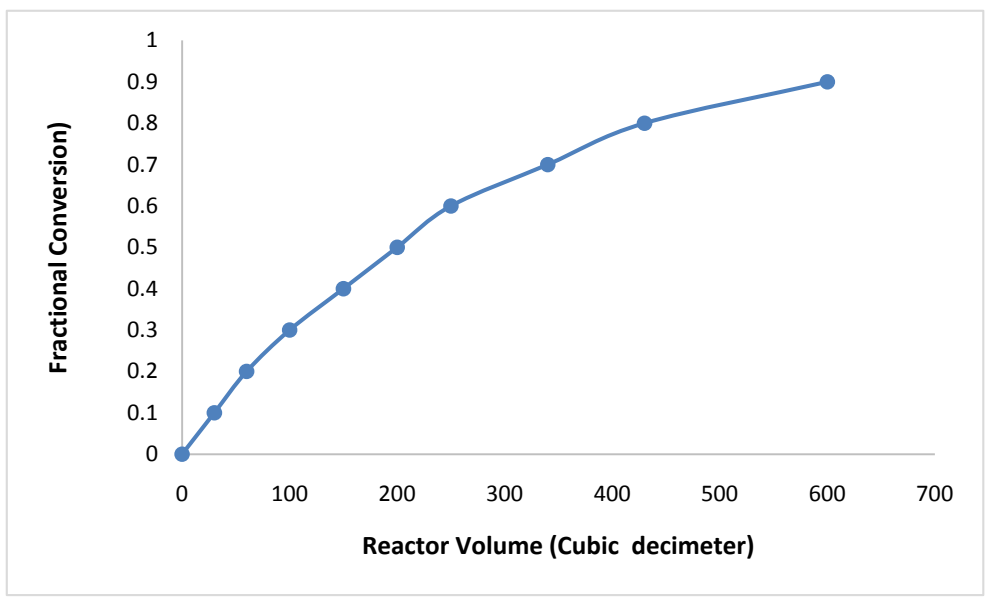

Figure 5. Variation of fractional conversion versus reactor volume.

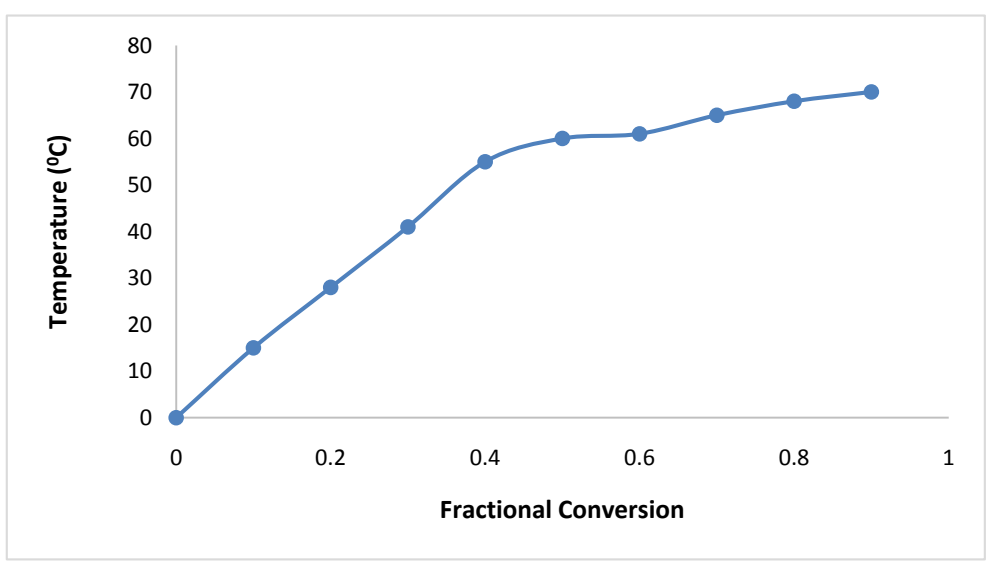

Figure 6. Temperature variation with fractional conversion. 


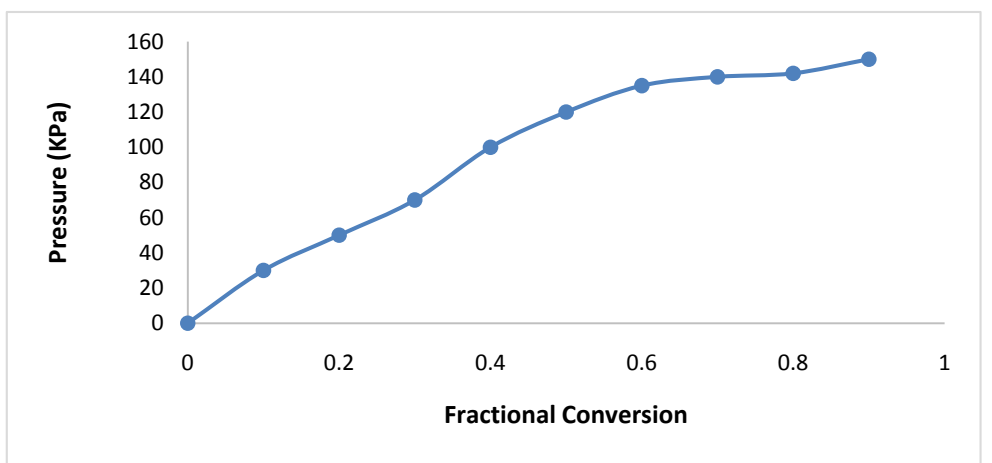

Figure 7. Variation of pressure with fractional conversion.

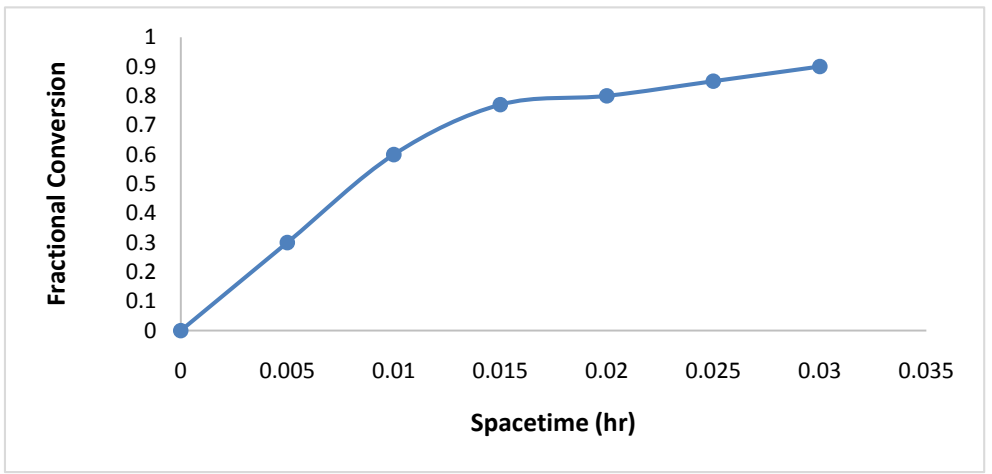

Figure 8. Space time variations with fractional conversion.

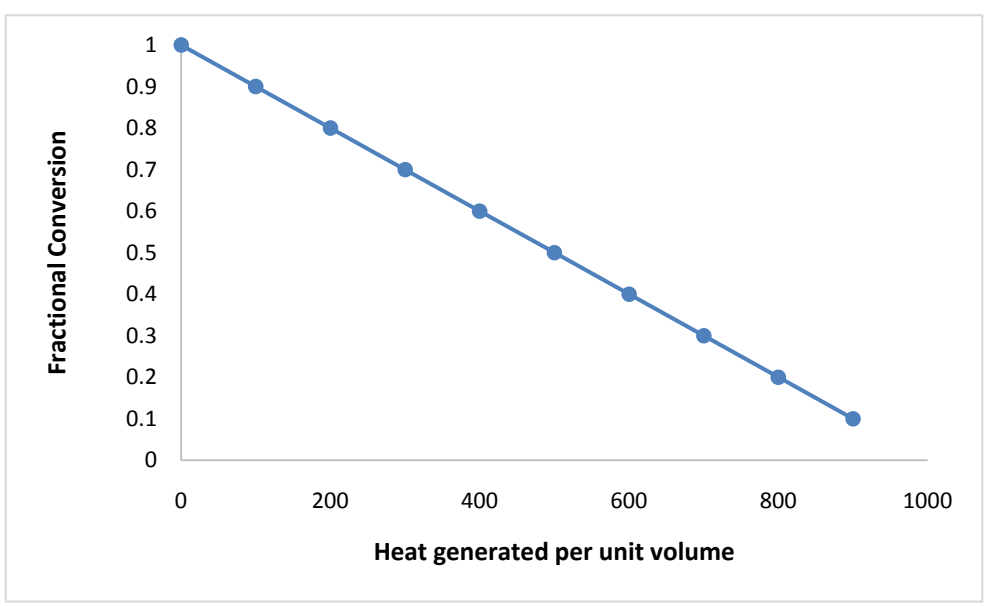

Figure 9. Heat load variation along reactor height.

Figure 8 shows that as the space time of the reactor increases, the fractional conversion of the propane to propene also increase. Hence, it could be concluded from the plot that the conversion is directly proportional to the total amount of time spent by the reacting species in the reactor. The more time the reacting species spend in the reactor, the more the yield of products.

\subsubsection{Heat Load}

The heat load is the amount of heat required in maintaining the temperature of 
the reaction process. It could be seen from Figure 9 that the fractional conversion is decreasing with an increase in the heat generated per unit volume as the reaction progresses.

\section{Conflicts of Interest}

The authors declare no conflicts of interest regarding the publication of this paper.

\section{References}

[1] Choudhary, V., Mondal, K.C. and Mulla, S.A. (2006) Non-Catalytic Pyrolysis of Ethane to Ethylene in the Presence of $\mathrm{CO}_{2}$ with/without Limited $\mathrm{O}_{2}$. Journal of Chemical Science, 118, 261-267. https://doi.org/10.1007/BF02708286

[2] Ghaza, E.C. and Mayourian, J. (2014) Ethylene Production Plant Design: Process Evaluation and Design II. Mc Graw Hill, New York.

[3] Gujarathi, A.M., Patle, D.S., Agarwal, P., Karemore, A.L. and Babu, B.V. (2014) Simulation and Analysis of Ethane. Cracking Processes, 45, 1-9.

[4] Erfani, G., Lowe, C. and Mayourian, J. (2014) Ethylene Production Plant Design: Process Evaluation and Design II. Cooper Union for the Advancement of Science and Art, 41, 131-143.

[5] Cameroon, G., Le, L., Levine, J. and Nagulapalli, N. (2012) Process Design for the Production of Ethylene from Ethanol. https://www.Researchgate.net

[6] Dutta, A., Chit, C.W., Karium, I.A. and Farooq, S. (2017) Ethylene From Natural Gas via Oxidative Coupling of Methane and Cold Energy of LNG. Computer Aided Chemical Engineering, 40, 1855-1860. https://doi.org/10.1016/B978-0-444-63965-3.50311-1

[7] Fabrega, F.M., Rossi, J.S. and d'Angelo, J.V. (2010) Exergetic Analysis of the Refrigeration System in Ethylene and Propylene Production Process. Energy, 35, 1224-1231. https://doi.org/10.1016/j.energy.2009.11.001

[8] Uses of Polyethylene. https://guichon-valves.com

[9] Uses of Polyvinylchloride. http://citeseerx.ist.psu.edu

[10] Uses of Ethylene. https://mafiadoc.com

[11] Application of Polyethylene in Chemical Industries. https://aspirationclasses.com 